\title{
Soğuk Savaş Sonrası Arktika Bölgesi Jeopolitiği ve Bölgesel İş Birliği Potansiyeli ${ }^{1}$
}

The Arctic Geopolitics in the Aftermath of the Cold War and the Potential of Regional Cooperation

Alp Yüce KAVAS 2

Geliş tarihi: 11.05.2019, Kabul tarihi: 16.09.2019, Basım tarihi: 25.10.2019

\section{Öz}

Arktika Bölgesi; gerek son y1llarda keşfedilen yoğun miktarda doğal kaynakları, gerekse küresel ısınmanın sonucunda deniz ulaşımına önemli bir alternatif sunma olasılığının ortaya çıkmasıyla daha fazla gündeme getirilmeye başlanmıştır. Bu tespitten hareketle çalışmamızda bir yandan Arktika Bölgesi'nin son y1llarda artan jeopolitik-jeostratejik ve jeoekonomik önemine bağlı olarak bölgedeki başlıca devletler arasında ortaya çıkan hukuksal tartışmalara ve rekabetin yansımalarına yer verirken diğer taraftan, Soğuk Savaş sonrası uluslararası ilişkiler disiplininde daha çok yer edinen neoliberal kurumsalcı, bölgeselci ve yeşil kuramcı yaklaşımları dikkate alarak, Arktika'da kalıcı bir iş birliği ortamını sağlayabilmede bölgesel ölçekte faaliyet gösteren uluslararası örgütlerin rolünü tartışmaya açacağı. Küresel 1sınma olgusunun bilimsel bir gerçeklik kazandığı günümüzde bölgenin çatışma değil örnek iş birliği merkezi olarak anılmasını sağlayacak mekanizmaların geliştirilebilmesi insanlığın geleceği için de yaşamsal önem taşımaktadır.

Anahtar Kelimeler: Arktika, Bölgesel Iss Birliği, Uluslararası Örgütler, Bölgeselcilik, Küresel Isinma

JEL Kodlar1: F53, N40, Q38

\begin{abstract}
Arctic region, due to its newly discovered abundant natural resources and to its emergence as a possibly advantageous alternative maritime route for commercial ferries induced by global warming, is brought on frequently in recent years. Considering this fact, we first aim to elaborate legal disputes and reflections of rivalry among major regional states due to the geopolitical-geostrategic and geoeconomical importance of Arctic region and then open to discuss the role of international organizations located in the region in point of constructing the propriate climate for a durable cooperation in the Arctic, taking in consideration neoliberal institutionalist, regionalist and green theorist approaches which gained more place within international relations discipline in post-Cold War era. In modern times, witnessing the global warming phenomenon as a scientific fact, the

\footnotetext{
${ }^{1}$ Bu çalışma, 19-22 Nisan 2019 tarihleri arasında Lefkoşa-K.K.T.C.'de gerçekleştirilen V. Afro-Avrasya Araştırmaları Kongresi’nde aynı başlıkla sunulmuş bildirinin makaleye dönüştürülmüşşeklidir.

2 Dr.

alpyucekavas@gmail.com

https://orcid.org/0000-0001-5686-026X
} 
declaration of Arctic region as a center of exemplary cooperation in lieu of regional severe conflicts is vitally essential for the mankind's future.

Key Words: Arctic, Regional Cooperation, International Organizations, Regionalism, Global Warming

JEL Codes: F53, N40, Q38

\section{Giriş}

Akademik literatür incelendiğinde Arktika (Kuzey Kutbu) bölgesine olan ilgide son y1llarda belirgin bir artış olduğu gözlemlenmektedir. Bölgeyle ilgili analiz ve değerlendirmelerin önümüzdeki yıllarda daha da önem kazanma olasılığı, meydana gelen gelişmelerden ve gezegenimizdeki iklimsel dönüşümden dolay1, yüksek görünmektedir. Bu tespitten hareketle çalışmamızda Arktika'daki iş birliği potansiyelini masaya yatırmanın yanı sıra bölgenin yakın gelecekte çatışma-rekabet eksenli olarak değil iş birliği merkezli olarak anılmasının yaşamsal öneminin ortaya konulmasına çalışacağız. Buradaki temel hareket noktamız bölgede iş birliğinin geliştirilmesi için gerekli potansiyelin salt ulus-devletlerin karşılıklı çıkarlara dayalı pragmatik yakınlaşmaları yoluyla değil daha fazla biçimde Arktika'da faaliyet gösteren uluslararası örgütler eliyle gündeme taşınması gerekliliğidir.

Diğer taraftan bölgede küresel 1sınma sürecine bağlı olarak yeni enerji kaynaklarının ortaya çıkmasının, halihazırda uluslararası sistemdeki başat oyuncu olma özelliğini sürdüren, özellikle bölgedeki kıyıdaş ulus-devletler arasında meydana getirdiği ciddi rekabet unsurunu da görmezden gelmek sağlıklı bir değerlendirme yapılmasına engel teşkil edecektir. Dolayısıyla bölgeyle ilgili çalışmalarda değinilen rekabet ve iş birliği unsurlarına çalışmamızda da yer verilmesi zorunlu görünmektedir. Bununla birlikte bölgedeki iş birliğinin kalıcı bir nitelik kazanmasının sağlanabilmesi için görüşlerimizi tartışmaya açarken neoliberal kurumsalc1, bölgeselci ve yeşil kuramcı yaklaşımlardan yeri geldikçe faydalanmayı amaçlamaktayız.

Çalışmamızda Arktika'yı incelerken öncelikle neden Soğuk Savaş sonrası dönemi tercih ettiğimizin ortaya konulması bunu yaparken de tarihsel bir arka plan sunulması gerektiğini düşünmekteyiz. Arktika'daki iş birliği potansiyelini tartışmaya açarken bölgenin jeopolitik-jeostratejik ve jeoekonomik öneminin ortaya konulmasını, bu yolla kıyıdaş ülkelerin sadece rekabet değil iş birliği için de temel motivasyon kaynağına işaret etmeyi uygun görmekteyiz. Bölgede sürdürülebilir iş birliği ortamı için ciddi bir tehdit unsuru olan rekabetçi yaklaşımları besleyen hukuksal tartışmalara ve güncel gelişmelere yer vermeden bölgeyle ilgili sağlıklı bir değerlendirme yapılamayacağı ortadadır. Öte yandan çalışmanın ana hedefi olan bölgesel iş birliğinin geliştirilmesindeki temel parametrelerin ortaya konulması ve yine 
bölgede faaliyet gösteren uluslararası örgütlerin kalıcı iş birliği iklimine sunabileceği katkılara da yer verilmesine çalışlacaktır.

\section{Tarihsel Arka Plan: Soğuk Savaştan Günümüze Arktika Bölgesi}

Kuzey kutup bölgesinin coğrafi olarak keşfi tartışmalı bir biçimde Antik Çağ’a kadar geri götürülmekle birlikte 9. yüzylldan itibaren Norveç kökenli Vikingli denizcilerin İzlanda, Grönland ve Kuzey Amerika'ya deniz seferleri gerçekleştirdikleri bilinmektedir. (Encyclopedia Britannica, 2019). 16. Yüzyıldan itibaren, o dönem Afrika ve Güney Amerika kıtasında etkili olan iyi donanımlı İspanyol ve Portekiz donanmaları nedeniyle Uzak Asya ile ticaret için alternatif yollar arayan, İngiliz ve Hollandalı denizciler bölgede keşifler gerçekleştirmeye başlamış, Ruslar ise özellikle 18. yüzyıldan itibaren bölgede keşif amaçlı deniz seferleri düzenlemişlerdir (Encyclopedia Britannica, 2019). Bundan sonra da bölgede kuşkusuz pek çok coğrafi keşif gerçekleştirilmiştir ancak Arktika'nın jeopolitik ve jeostratejik öneminin ortaya çıkması noktasında Soğuk Savaş döneminin özel bir yeri söz konusudur. Bu nedenle Soğuk Savaş döneminde bölgenin üstlendiği role kısaca değinmeyi uygun görmekteyiz.

Soğuk Savaş döneminin iki süper gücü ABD ile SSCB arasındaki özellikle siyasi, ideolojik ve askeri alanlardaki rekabet ve nüfuz mücadelesinde Arktika'nın kendine özgü bir biçimde stratejik bir rol üstlendiği görülmektedir. Bundaki başlıca etken olarak ise bölgenin, her iki süper gücün nükleer silahların kullanılması durumunda, en kısa yolu oluşturması gösterilebilir (Mikkola, 2019:3). Soğuk Savaş sırasında nükleer dehşet dengesinin korunabilmesi sayesinde Arktika bölgesi böylesine kötü şöhretli bir stratejik rol üstlenmek zorunda kalmaktan kurtulmuştur. Ayrıca bölgedeki savaş gemilerinin ve denizaltıların geçişinin kontrolü ve hatta gerektiğinde engellenebilmesi için her iki süper gücün askeri yapılanmaya gittikleri görülmektedir zira Arktika Denizi’nin nevi şahsına münhasır yapısı denizaltıların geçişinin takibini zorlaştıran bir etkendir (Aliyev, 2019). Yine bu dönemde özellikle Kanadalı ve Amerikan savaş uçakları Sovyet bombardıman uçaklarını önleme amaçlı son sayıda uçuş gerçekleştirmiş, bu nedenle Sovyet Hava Kuvvetlerinin 1980'lerden itibaren o dönem için gelişmiş teknolojiye sahip MíG-31 savaş uçaklarını bombardıman uçaklarını koruma amacıyla bölgede konuşlandırmıştır. (Aliyev, 2019).

Arktika’nın Soğuk Savaş döneminde büyük ölçüde iki süper gücün askeri rekabet alanı olarak gündemde kalmasına karşın 1980'li yılların ortasında, Mihail Gorbaçov'un SSCB'de iktidara gelmesiyle birlikte Sovyet devlet aygitı ve toplumsal yapıdaki dönüşümlere paralel olarak, bölgeye dönük algılamada da değişiklik baş göstermiştir. Nitekim Gorbaçov'un 1987 yllinda Murmansk kentinde gerçekleştirdiği ünlü konuşmasında "barış bölgesi" olarak tanımladığ1 Arktika'nın süreç içinde nükleer silahlardan arındırılması, bölgede barışçıl amaçlı çokuluslu bilimsel faaliyetlere ağırlık verilmesi ve 
konumuz açısından en önemli görünen çevrenin korunmasıyla ilgili iş birliğine gidilmesi konularındaki gerekliliğe vurgu yapması dikkat çekicidir (Gorbaçov, 1987). Soğuk Savaş sürecinin yumuşamaya girmesi ve ABD'nin Gorbaçov dönemindeki SSCB'yi eskisi kadar tehdit olarak algilamaması sonucunda karşılıklı yapıcı diyalogların geliştirilmeye başlanmasıyla bölgesel iş birliği için önemli bir başlangiç umudunun yeşermesi söz konusu olabilmiştir.

Soğuk Savaşın sona ermesi ve SSCB'nin 1991 sonunda dağılmasıyla birlikte bölgenin askeri-stratejik açıdan önemi geçici olarak sona ermiştir. SSCB'nin siyasi ardilı olan Rusya Federasyonu'nun (buradan sonra 'Rusya' olarak ifade edilecektir) 1990’lı ylllarda içine düştüğü derin siyasi, ekonomik ve toplumsal buhranlarla mücadele etmek zorunda kalması bölgeye dönük ilgisini oldukça azaltmıştır. Batılı ülkeler de Soğuk Savaş sonrası bölgenin askeri-stratejik öneminin bütünüyle sona erdiğini düşünerek Arktika’ya olan ilgililerini bu dönemde benzer biçimde azaltmışlardır. 2000'li yıllara gelindiğinde ise küresel 1sınmanın bölgede neden olacağı yıkıcı etkilerin yanı sıra ekonomik-ticari boyutta sağlayabileceği firsatlara bağlı olarak Rusya başta olmak üzere pek çok ülkenin dikkati yeniden Arktika'ya çevrilmiş ve bölgede aynı anda hem rekabet hem de iş birliği unsurları ortaya çıkmışır.

\section{Arktika'nın Günümüzdeki Jeopolitik-Jeostratejik ve Jeoekonomik Önemi}

Arktika bölgesinin coğrafi konumuyla ilgili tam bir netlik bulunmamakla birlikte yaygın olarak kabul gören tanımlama 66. Kuzey paraleli ile Kuzey Kutup noktası arasındaki sahayı kapsamakta, bu çerçevede 9 milyon kilometrekaresini karaların oluşturduğu yaklaşı 27 milyon kilometrekareye denk düşmektedir (Kavas, 2014). Bu coğrafi tanımlama dikkate alındığında; ABD, Rusya Federasyonu, Kanada, Norveç, İsveç, İzlanda ve Danimarka'nın kara parçalarını kapsadığı görülmektedir. Söz konusu ülkeler içerisinde kıta sahanlıklarını genişletme amaçlı girişimde bulunanlara ve bu girişimlerin doğurduğu hukuksal tartışmalara aşağıda değinilecektir.

21. yüzyılda Arktika'nın gerek jeopolitik-jeostratejik gerekse jeoekonomik önemini oluşturan iki temel sacayağı bulunmaktadır. İlk olarak; bölgede son dönemde keşfedilen ciddi ölçekli yer altı zenginlikleri söz konusudur. Bölgedeki yer altı zenginlikleri ile ilgili tahmin ve değerlendirmeler değişiklik göstermekle beraber ifade edilen değerler önemli ipuçları vermektedir. Örneğin 2008 yllında ABD İçişleri Bakanlı̆̆ı'na bağlı Jeolojik Araştırma Ajansı bölgede 90 milyar varil petrol, 47 trilyon metreküp doğalgaz ve 44 milyar varil LNG rezervi olduğunun ve burada sıralanan miktarların \%84'ünün açı denizde yer aldığının tahmin edildiğini açıklamıştır. (USGS, 2008). Rakamlar tek başına verildiğinde yeterince fikir edinmek mümkün olmayabilmektedir bu nedenle oransal olarak incelendiğinde, 2013 yll verilerine göre, dünya petrol rezervlerinin yaklaşık \%6'sına, dünyanın 
kanıtlanmış doğalgaz rezervlerinin ise yaklaşık dörtte birine denk düştüğü görülmektedir (Kazokoğlu, 2014). Böylesine ciddi ölçekli yer altı zenginliklerinin bulunduğu bir bölgede konumlanan oyuncuların ekonomik çıkarları noktasını dikkatini çekmemesi elbette düşünülemez.

İkinci sacayağını ise, özellikle küresel 1sınmayla birlikte iklim koşullarındaki değişime bağlı olarak, bölgedeki deniz ulaşımı ve ticaretinin daha avantajlı hale gelme olasılığının yüksekliği oluşturmaktadır. Arktika bölgesinin yakın gelecekte küresel 1sınma süreciyle de bağlantılı olarak aşağıdaki deniz taşımacılık güzergahları açısından öneminin artacağı tahmin edilmektedir (The Geography of Transport Systems, 2017):

- Kuzey Deniz Yolu (KDY): Rusya'nın Arktik Okyanusundaki kıyılarından geçen KDY deniz ticaret yolları açısından potansiyeli en yüksek olanıdır. Bunun en büyük nedeni de küresel 1sınma süreciyle birlikte hat üzerindeki buzlanmanın en çok yavaşlama hatta uzun vadede ortadan kalkma olasılığının bulunmasıdır. Doğu Asya'dan Batı Avrupa'ya günümüzde Süveyş Kanalı üzerinden yaklaşık $21.000 \mathrm{~km}$ mesafesindeki deniz yolu ulaşımı bu hat sayesinde 12.800 km'ye inecek ve bu şekilde 10-15 günlük bir zaman kazanımı mümkün olabilecektir.

- Kuzeybatı Geçidi: Kanada ve ABD (Alaska) kıyılarından geçen hattın 2020'li yllarla birlikte önemli bir alternatif deniz yolu olması beklenmektedir. Günümüzde Doğu Asya'dan Batı Avrupa'ya deniz yolu ulaşımı Panama Kanalı üzerinden $24.000 \mathrm{~km}$ uzunluğundayken, bu hattın buzdan arındığı dönemlerde $13.600 \mathrm{~km}$ civarına kadar inebilecektir. Küresel ısınma sürecinin hızlanması durumunda hattın yaz ayları dışında da kullanımı mümkün olabilecektir.

- Kutup-ötesi Deniz Yolu: Bering Boğazıyla Rusya'nın Murmansk oblastını doğrudan birbirine bağlayacak bu hat mevcut koşullarda kullanışlı değildir zira ciddi oranda buzlanma söz konusudur. Bununla birlikte küresel ısınma sürecinin hızlanmasıyla birlikte bu hattın da alternatif olarak devreye girmesi beklenmektedir.

- Arktika Köprüsü: Rusya'nın Murmansk, Norveç'in Norvik ve Kanada'nın Churchill limanlarını birbirine bağlaması hedeflenen bu hattın özellikle tahıl ürünleri taşımacıllğında faydalı olabileceği varsayılmaktadır. Diğer üç hattan farklı olarak tüm Arktik boyunca değil, Batı Avrupa ile Kuzeybatı Amerika arasındaki deniz ulaşımının gerçekleştirilmesine dönük bir projelendirmedir. Mevcut buzlanma koşulları bu hattın yakın vadede kullanımını belirsiz kılmaktadır.

Kuşkusuz yukarıda sıraladığımız hatlar küresel 1sınma sürecinin hızlanmasına bağlı olarak Arktika Bölgesindeki buzulların erimesi, bu yolla deniz yolu ulaşımının elverişli hale gelmesi varsayımına dayanmaktadır. 
Özellikle Çin'in son yıllarda iddialı bir biçimde ortaya koyduğu Bir Kuşak Bir Yol (BKBY) projesi kapsaminda kendisini gerek kara gerekse deniz yoluyla Avrupa'ya bağlaması mümkün olduğunda Arktika'nın alternatif bir deniz yolu ulaşım bölgesi olarak buna ne ölçekte cevap verebileceği henüz belirsizdir. Bununla birlikte bölgedeki yer altı zenginliklerinin çıkarım ve işletimi mümkün hale gelmesiyle birlikte kullanılacak bu deniz yolu hatlarının ulaşım ve ticaret açısından sağlayacağı zaman-kazanç avantajlarına bağlı olarak cazibesinin artma olasillğı yüksek görünmektedir.

\section{Arktika Bölgesi'nin Hukuksal Statüsü ile İlgili Tartışmalara Genel Bakış}

Bölgedeki zengin yer altı kaynakları ve gelecekte önemli alternatif bir deniz yolu haline gelme potansiyeli taşıması bölgede kıyıdaş olan bazı ülkeler arasındaki rekabeti kaçınılmaz olarak doğurmuştur. $\mathrm{Bu}$ bağlamda, çalışmamızda bölgenin güncel önemine vurgu yapmak adına, 2000'li yıllardan itibaren meydana gelen bazı hak iddialarına kısaca değinmeyi ve söz konusu iddialar üzerinden bölgedeki gerilimin artma nedenlerine sşık tutmayı amaçlamaktayız.

Yeni binyılda bölgeyle ilgili hak iddiasını hukuki çerçevede uluslararası kamuoyunun dikkatine sunan ilk ülke Rusya olmuştur. BM Deniz Hukuku Sözleşmesi’nin (BMDHS) 76. maddesinin 5. paragrafinda; normal durumlarda 200 deniz miline kadar ilan edilebilen kıta sahanlı̆̆ının özel şartlarda 350 deniz miline kadar uzatılabileceği belirtilmektedir (BMDHS,1982). Rusya da ilgili maddeden kendi ekonomik çıarları adına yararlanabilme adına ilgili maddenin 8. paragrafı gereğince oluşturulan BM Kıta Sahanlığı Sınırları Komisyonu'na (buradan sonra kısaca 'Komisyon' olarak ifade edilecektir) 2001 yılında başvurarak Arktika'daki kıta sahanlığını hukuki düzlemde genişletmeyi hedeflemiştir. Komisyon Rusya'nın söz konusu başvurusunu dikkate almış ancak 2002 yllında iddialarını destekleyecek ek bilimsel kanıtlar talep etmiştir (Gül, 2014:4). Rusya'nın hak talebi beklenildiği gibi diğer kıyıdaş ülkeler tarafindan olumlu karşılanmamış hatta bölgede istikrarsızlık unsurunu artıracağı öne sürülerek kınanmıştır (Kavas, 2014). 2007 yllında dönemin Rus Doğal Kaynaklar Bakanı Yuri Trutnev, Rusya'nın Arkrika ile ilgili hak iddiaları kabul edildiği takdirde yaklaşı 1,2 milyon kilometrekarelik bir alanda Rus bilim insanlarının bilimsel çalışmalara başlayabileceğini, özellikle deniz altındaki Lomonosov sıradağlarının 5 milyar tondan fazla yakıta eşdeğer bir potansiyele sahip olduğunu ifade etmiştir (Sputnik, 2007). Burada Rusya'nın Lomonosov ve Mendeleev sıradağlarının "denizaltı dağ sırtı" olarak değil "denizaltı yükseltisi” olarak nitelendirilmesine çalısttğı, bu yolla kita sahanlığını anakaranın uzantısı olarak kabul ettirerek BMDHS'te belirlen maksimum 350 deniz miline kadar uzatılma zorunluluğundan kurtulmayı amaçladığını hatırlatmakta yarar vardır (Matz-Lück, 2009:250-251). 
Rusya'nın 21. yüzyıl başındaki hak talebini hukuki bir çerçeveye oturtma girişimi bölgede kıyıdaş olan diğer oyuncuları da harekete geçirmiştir. Söz konusu ülkelerden Kanada, Norveç ve Danimarka kendi ekonomik ve siyasi çıkarları dahilinde aşağıdaki hak taleplerini uluslararası kamuoyuna duyurmuşlardır (Bentzen ve Hall, 2017:4-6):

- BMDHS'yi 2003'te onayan Kanada 2013'te Komisyon'a başvuruda bulunarak hem Atlantik hem de Arktika Okyanusları içerisindeki kıta sahanlığının sınırlarının genişletilmesini talep etmiş böylelikle yaklaşık 1,2 milyon kilometrekarelik bir alanda hak iddia etmiştir. Kanada'nın bölgedeki hak talebi Rusya'nın da talip olduğu, Lomonosov ve Mendeleev Sıradağlarının bir kısmını da kapsamaktadır.

- Grönland Adası'nın bağlı bulunduğu Danimarka da 2014 yılında Komisyon'a başvurarak Arktik Okyanusu'nda 200 deniz milinin ötesinde 900.000 kilometrekareye yakın bir alanda hak talebinde bulunmuştur.

- 2006'da BMDHS'yi onayan Norveç aynı y1l Komisyon'a başvurarak Norveç yatağından 200 deniz mili ötesinde münhasır ekonomik bölge olarak ilan etmek amacıyla Barents'teki "Mazgal Boşluğu" (Loophole), Arktik Denizindeki Batı Nansen Havzası ve Norveç Denizindeki "Muz Boşluğu'nda" (Banana Hole) hak talebinde bulunmuştur. Barents Körfezi aşağıda değineceğimiz 2010'da Rusya ile Norveç arasında imzalanan Murmansk Antlaşması ile çözüme kavuşmuştur. Buna karşıllk bu iki ülke 1920 yllında imzalanan Svalbard Antlaşması'ndan doğan hangi eşit muamele haklarının deniz alanlarında uygulanması gerektiği ve Svalbard ile Grönland'ın kıta sahanlıklarının deniz sınırlarının belirlenmesi hususlarında anlaşmazlıklarını sürdürmektedir.

Henüz BMDHS'yi imzalamayan ABD bu nedenle bölgeye dönük olarak resmi bir hak talebinde bulunamamaktadır. Bununla birlikte Rusya ile özellikle Bering Boğazı ile ilgili bir uyuşmazlığın süregeldiği söylenebilir. 1990'da o dönem SSCB Dışişleri Bakanı Eduard Şevardnadze ile ABD’li mevkidaş1 James Baker'in soy isimlerini taşıyan bir anlaşmayla Bering Boğazı'nın statüsü çözüme kavuşturulmak istendiyse de önce SSCB daha sonra da siyasi mirasçısı Rusya'nın anlaşmayı onamaması nedeniyle hukuki tartışma süregelmektedir (Kavas, 2014).

\section{Bölgedeki Rekabetin Güncel Yansımaları}

Arktika'da kıyıları bulunan başlıca ülkelerin aralarındaki uyuşmazlıkları henüz çözüme kavuşturamamış olmaları nedeniyle özellikle Rusya ve diğer bazı kıyıdaş ülkeler arasındaki gerginlik zaman zaman askeri hareketliliğe dönüşebilmektedir. Bunda Rusya'nın bölgedeki hak taleplerini kabul ettirebilme amacıyla sıkça askeri güce başvurabileceğini vurgulamasının yanı sıra diğer başlıca kıyıdaş ülkelerin Rusya'nın bu tavrına karşı askeri 
faaliyetlere yönelebilmelerinin de rolü bulunmaktadır. Bölgede askeri hareketliliğin artması yakın gelecekte sıcak çatışma riskini de beraberinde getirmekte, dolayısıyla hem bölgesel hem de küresel düzeylerde barış ve istikrarın sürdürülebilmesi noktasında ciddi bir tehdit unsuru haline gelmektedir.

2007 yllında Arktika Bölgesindeki hak iddiasını güçlendirmek adına küçük bir Rus denizaltısı tarafından Kuzey Buz Denizi’nin dibine titanyum kaplı Rus bayrağının dikilmesi ve 2012'de yaklaşık 7.000 kişilik askeri personel ve 20 askeri geminin kattlımıla tatbikat gerçekleştirmesi önemli göstergelerden sayllabilir (Singh, 2013). Yine 2014'te patlak veren Ukrayna krizi sonrasında Rusya'nın Arktika'daki askeri varllğını artırdığı, bu bağlamda bölgeye yeni uçak pistleri ve radar istasyonları inşa etmeyi amaçladığ1 gözlemlenmektedir (Cazala, 2016:172-173). Diğer taraftan Rusya'nın bölgeyle ilgili hırslarını yansıtması bakımından en önemli adımın ise 2018 sonbaharında, 1981 yllından bu yana en büyük katıllımla (Rus yetkililere göre 300.000 asker) Japon Denizi, Bering Boğazı ve Ohotsk Denizinde gerçekleştirilen Vostok askeri tatbikatı olduğunu belirtmek yanlış görünmemektedir (Sputnik Türkiye, 2018). Bazı NATO yetkilileri söz konusu katılımın belirtildiği kadar yüksek olmadığı görüşündedir ancak söz konusu tatbikata Çin askeri unsurlarının da katılmış olması açıkça ABD başta olmak üzere Batılı ülkelere ve Asya-Pasifik'teki müttefiklerine açı bir siyasi ve askeri mesaj içermektedir (Johnson, 2018). Konumuz açısından Vostok tatbikatının önemi ise Rusya'nın gerektiğinde askeri unsurlarını Kutup Bölgesi yakınında hareketlendirebileceğini göstermiş bulunmasıdır.

Rusya'nın son yıllarda siyasi ve ekonomik çıarlarını korumak adına askeri güce başvurmakta tereddüt göstermeyeceği hatta gerekirse Çin'in de siyasi ve askeri desteğini arkasına alacağı mesajını vermesi üzerine NATO'nun vereceği muhtemel yanıta çevrilmiştir. Nitekim Vostok tatbikatından kısa bir süre sonra Hollanda, Almanya ve Norveç'te yaklaşık 50.000 kişilik askeri personelin katılımıla bir NATO tatbikatı gerçekleştirilmiş, tatbikat senaryosu Norveç'in "hayali düşman" ülke tarafindan işgal edilmesi sonrasına göre düzenlenmiştir. (Özkan, 2018). Burada dikkat çekici husus Norveç'in işgale uğraması ve diğer NATO müttefiklerinin de yardıma geldiği bir senaryoya göre askeri tatbikat düzenlenmiş olmasıdır. Burada bahsedilen "hayali düşmanın" Rusya olarak algılanacağını tahmin etmek zor değildir. Kanada ise 2019 yllında küçük katılımlı (yaklaşık 500 askeri personel) ancak Fransa, Finlandiya ve Norveç'ten de askeri unsurları içeren Nanook-Nunalivut tatbikatını gerçekleştirerek bölgedeki varlığını hatırlatır bir konumlanma almıştır. (Defence Point, 2019). 


\section{Bölgede İş Birliğinin Temel Parametreleri}

Arktika'da yaşanan hukuksal tartışmalar, bölge ülkelerinin kıta sahanlıklarını genişletmek için kıyasıya rekabet içerisinde girmesi hatta bu uğurda gerektiğinde askeri güce başvurmaktan geri durmayacakları mesajını vermeleri bölgesel barış ve istikrarın gelişimi için son derece olumsuz etkenler olarak karşımıza çıkmaktadır. Bu koşullarda "acaba bölgede kalıcı barışı ve iş birliği iklimini yeşertme olasıllğı büyük ölçüde ortadan kalkmış mı görünmektedir?" sorusu ister istemez akla gelmektedir. Yukarıdaki başlıklar incelendiğinde ilk bakışta yanıt olumlu görünmektedir ancak o zaman bölgesel ölçekte faaliyet gösteren uluslararası örgütlerin işlev ve çalışmalarının anlamsızlaşacağı sonucuna ulaşmak zorunda kalırız. Diğer taraftan Rusya ve diğer bölgeye kıyıdaş ülkelerin arasındaki rekabet hatta potansiyel çatışma riskinin artık 'nükleer tehdit' boyutuna kadar uzanabildiği bir dehşet sürecine evrildiğini hatırlatmakta yarar görünmektedir (Hürriyet, 2019). Bu koşullarda artık bölge için rekabet ve çatışmanın değil iş birliği olanaklarının ön plana çıkarılması elzem görünmektedir.

Rusya ile Norveç'in 2010 yllında Murmansk'ta imzaladığı antlaşmayla, yaklaşı1k 10 milyar varil petrol rezervinin bulunduğu Barents Denizi’ndeki 175.000 kilometrekarelik alandaki 40 yıldır süren anlaşmazlığ1 sonlandırmaları ve iki ülkenin sınırlarını kesinleştirmeleri bölgesel sorunlara çözüm ve iş birliğinin bütün olumsuz gelişmelere rağmen gerçekleştirilebileceğinin somut bir örneği olarak karşımıza çıkmaktadır (NTV, 2010). Resmi adı "Norveç Kralluğ ile Rusya Federasyonu Arasında Deniz Sınırlandırması ile Barents Denizi ve Arktik Okyanusu'nda İş Birliğini İçeren Antlaşma" olan Murmansk Antlaşmasının 4. ve 5. Maddeleri iki ülkenin balıkçılık ve hidrokarbon kaynaklarının sınırlandırılmasını ele almaktadır (Murmansk Antlaşması, 2010). İlgili antlaşmanın 4. maddesi tarafların balıkçlık alanlarında yakın iş birliğini sürdüreceklerini ve denizsel çevrenin korunmasını birlikte üstlenmelerini yükümlerken, 5. madde herhangi bir hidrokarkon yatağının sınır hattını aşması durumunda antlaşmadaki 2. ekte düzenlenen ortak üretim (unitisation) anlaşmasında belirlenen esaslara işaret etmekte, bu şekilde bölgede karşı tarafin onayı alınmaksızın tek yanlı hidrokarbon keşif ve çıkarımının önüne geçilmesi hedeflenmektedir. Rus enerji şirketi Rosneft ve Norveçli enerji şirketi Statoil 2012'de Rusya'nın kuzeyindeki Yamal-Nenets Okrug'una bağlı SeverolKomsomolskoye petrol sahasında ortak keşif ve çıkarıma dayalı kapsamlı antlaşmaya imza atarken Murmansk antlaşmasından güç aldıkları açıktır (Staalesen, 2017). Şüphesiz Murmansk Antlaşmasının imzalanması iki ülkenin bölgedeki yer altı zenginliklerine yönelik hırslarını ortadan kaldırmamıştır ancak en azından bölgede rasyonel yaklaşım ön plana çıkarıldığında yapıcı iş birliği ikliminin yeşerebileceğini göstermesi bakımından önemli ve anlamlı bir adım olmuştur. 
Bölgede kalıcı barış ve iş birliğinin geliştirilmesi açısından bir başka umut verici gelişme ise 2008 yllında Grönland'ın Illulisat kentinde ABD, Kanada, Rusya, Danimarka ve Norveç'in katılımıyla gerçekleştirilen Arktika Okyanusu Konferansi'nda sunulan bildiri olmuştur. Söz konusu bildiride taraflar uluslararası deniz hukukuna uygun biçimde hareket edeceklerini ve muhtemel toprak uyuşmazlıklarının yine uluslararası hukuk normlarına uygun biçimde çözülmesinden yana olacaklarını ilan etmişlerdir (Yılmaz ve Çiftçi, 2013:9). İlgili metindeki en dikkat çekici vurgulardan birisi de beş ülkenin Arktika'nın özgün ekosisteminin korunması, bölgede deniz taşımacılığının geliştirilmesi ve yerli halklarının haklarının gözetilerek yaşam koşullarının iyileştirilmesi için gayret göstereceklerini ifade etmeleridir (Illusat Declaration, 2008). Bildiride henüz BMDHS'yi imzalamayan ABD’nin de yer alması bölgesel iş birliğinin geliştirilmesindeki rolünü göstermesi bakımından anlamlıdır.

Devletlerin Arktika'da aralarında uzlaşarak iş birliği girişimlerinde bulunmalarının yanı sıra devlet dışı oyuncuların da kalıcı iş birliği ikliminin oluşması için çaba sarf ettiği görülmektedir. Bunlar içerisinde bir sivil toplum kuruluşu (STK) olan Uluslararası Arktika Bilim Komitesi'nin (IASC) özel bir yeri olduğu düşüncesindeyiz. 1990 yllında kurulan IASC amacının bölgede hemen her alanda bilimsel araştırmaları teşvik etmek ve kolaylaştırmak olduğu belirtmekte, bunu yaparken disiplinler aras1 araştırmaları destekleyeceğini vaat etmektedir (IASC Resmi Sitesi). İleride değineceğimiz küresel ısınmanın meydana getireceği felaketlerin boyutlarıyla ilgili tahminleri ve olası önlemleri geliştirmekte IASC gibi oluşumların önemli katkı sunma potansiyelleri bulunmaktadır.

\section{Arktika'da Faaliyet Gösteren Uluslararası Örgütlerin Bölgesel İş Birliğindeki Muhtemel Rolü}

Arktik Bölgesine yönelik olarak faaliyet gösteren başlıca üç bölgesel örgüt mevcuttur: Arktika Konseyi, Barents Avrupa-Arktika Konseyi ve İskandinav (Nordik) Konseyi. 1996 yllinda Ottawa Bildirisi ile kurulan Arktika Konseyi'nin üyeleri; ABD, Kanada, Rusya, Danimarka, İzlanda, Finlandiya, İsveç, Norveç ve İzlanda'dır ve hükümetler arası bir forum görünümündedir. Konseyin başlıca ilgi ve çalışma alanları olarak sürdürülebilir kalkınma, çevrenin korunmasıyla ilgili önlemler sıralanmaktadır (Gül, 2014:6). Gerek bünyesindeki gözlemci ülkelerle birlikte devlet statüsünde olmayan unsurların, karar alma sürecinde etkin biçimde yer alamamalarına karşın, oluşturulan çalışma gruplarında yer alabilmeleri, gerekse bölgedeki altı yerli halkın Konsey'in daimi katılanları sayılmaları örgütün ulus-aşırı (transnational) ve hükümet-aşırı (transgovernmental) özelliğine işaret etmektedir (Byers, 2017:382). Rusya'nın 2014'de yaşanan Ukrayna krizi sonrasında diğer üye ülkelerle siyasi açıdan uyuşmazlığa düşmesine karşın 2015 yllında Arktika'daki deniz iş birliği projelerine destek 
vermesi ve de 2013 yllindan beri düzenli toplanan Arktika Konseyi Bilimsel İş Birliği Görev Gücünde ABD ile ortak başkanlı̆̆ sürdürmekte sakınca görmemesi dikkat çekici gelişmelerdir (Byers, 2017:387). Böylelikle üye ülkelerin aralarındaki siyasi uyuşmazlıklara rağmen deniz ve çevresel konularda uluslararası örgüt şemsiyesi altında iş birliğine yönelmekte beis görmediklerinin açık göstergesidir.

Örgütün inisiyatifiyle üye ülkeler arasında 2011 yllında imzalanan Arktik Arama ve Kurtarma Anlaşması bölgesel iş birliğini geliştirmek noktasında önemli bir adım olmuştur. Resmi adı "Arktika'da Hava ve Denizde Arama ve Kurtarmada İş Birliği Üzerine Anlaşma" olan belgenin ikinci maddesinde ilgili anlaşmanın amacı olarak Arktika bölgesinde hava ve denizde arama ve kurtarma operasyonlarında iş birliği ve eşgüdüme gidilmesi olarak belirtilmiştir. (Arktika Arama ve Kurtarma Anlaşması, 2011). Yine Konsey'e üye ülkeler 2017'de Arktika'da bilimsel çalışmaları eşgüdümlü yürütmek üzere resmi adı "Arktika'da Bilimsel Çalışmaları Geliştirme Anlaşması" olan bir anlaşma imzalamışlardır (Arktika Bilimsel Çalışmaları Geliştirme Anlaşması, 2017). 20 maddeden oluşan anlaşmanın 2. maddesinde Arktika bölgesiyle ilgili bilimsel bulguların geliştirilmesindeki etkinliğin artırlması amaç olarak belirtilmekte, 10. Maddede ise katılımcıların faaliyet ve yükümlülüklerinin uluslararası hukuk çerçevesinde ele alınacağına işaret edilmektedir. Bu durum Arktika'da bölgesel iş birliğinin hukuksal zemine oturtularak kalıcılaşması ve eşit katılımcılığın tesisi yönünde önemli adımlar atıldığının göstergesidir.

Arktika Konseyi'nin halihazırda üye ülkeleri zorlayıc1 ve alınan kararlarının uygulanmaması durumunda yaptırım uygulamasını sağlayacak mekanizmalardan yoksun olması nedeniyle zayıf bir görüntüde olması fili olarak üyeler arasında etkisi olmadığ1 anlamına gelmemekte, aksine son yıllarda bünyesindeki çalışma gruplarının raporları doğrultusunda özellikle çevresel konularda gündem oluşturabilmesi ve 2013'te göreve başlayan Sekreterlik sayesinde sıradan bir hükümetler arası forumdan kurumsallaşmış bir uluslararası örgüte dönüşme yolunda ciddi adımlar atmakta, bu yolla daha etkin bir bölgesel oyuncuya dönüşmektedir. (Knecth, 2013:13-14). Konsey bünyesinde Arktika İzleme ve Değerlendirme Programı (AMAP), Arktika'daki Flora ve Faunanın Korunması (CAFF), Acil Önleme, Hazırlık ve Karşılık Verme (EPPR), Arktika Deniz Çevre Korunması (PAME) ve Sürdürebilir Kalkınma Çalışma Grubu (SDWG) olmak üzere 6 çalışma grubu ve çeşitli dönemlerde görevlendirilip görevini tamamlamış 11 görev gücü (task force) bulunmaktadır (Arktika Konseyi Resmi Sitesi, 2019). Günümüzde henüz doğrudan bağlayıcı özellikleri bulunmasa da söz konusu çalışma gruplarının ve görev güçlerinin ortaya koyduğu çalışmalar bölgede etkin ve kalıcı bir iş birliği ortamının oluşturulmasında önemli rol oynamaktadırlar. Çalışma gruplarında gözlemci üye ülkelerden de uzmanlar görev alabilmekte ancak Konsey'e üye olan ülkeler ilgili raporlar 
doğrultusunda alınacak kararlarda son sözü söylemektedirler. 2019'dan itibaren iki yıllığına İzlanda Arktika Konseyi'nin dönem başkanlığını üstlenmeye başlamıştır. İzlanda'nın dönem başkanlığı gündeminde Arktika Denizi çevre ve iklimi, yeşil enerji çözümleri, bölgedeki halk ve toplulukların konumu, deniz ürünlerinden daha fazla verim elde etmeyi amaçlayan Mavi Biyoekonomi Projesi, bölgede cinsiyet eşitliği gibi çevresel ve toplumsal konular bulunmaktadır (Iceland Monitor, 2019).

1993 yllında Norveç’in girişimiyle kurulan Barents Avrupa-Arktika Konseyi'nin (BAAK) üyeleri Norveç, Danimarka, İzlanda, Finlandiya, Rusya, İsveç ve Avrupa Komisyonu'dur. 2017'den bu yana dönem başkanlığını yürüten İsveç'in Dişişleri Bakanı Margıt Waltsröm örgütün temel ajandasının olarak yine sürdürülebilir kalkınmayı ve Paris İklim Anlaşması çerçevesinde çevresel sorunların çözümü olacağını belirtmektedir (Swedish Chairmanship Program, 2017). Yine İsveç'in dönem başkanlığ1 sırasında hazırlanan ve konumuz açısından önemli olduğunu düşündüğümüz Çevre Üzerine Çalışma Grubu (WGE) 2018-2019 programında 2018'de Avro-Arktika'da iş birliği ulusal, bölgesel ve yerel düzeylerde gerçekleştirilmesinin 25. yllının kutlandığına işaret edilirken, 2017-2019 yılları arasında bölgede sürdürebilir kalkınmanın sağlanmasına odaklanılacağ1 vurgulanmaktadir. (Swedish Chairmanship, Working Group on Environment). Programda; iklim değişikliğine ayak uydurabilme noktasında bölgesel iş birliğinin geliştirilmesi, bir yandan Barents bölgesindeki yeni firsatların değerlendirilmesi, öte yandan 2015'te imzalanan Paris Anlaşmasının gereklerine katkıda bulunulması, çevresel açıdan tehlike sahalarının (hot spots) giderilmesi için destekleyici çalışmalar yürütülmesi, suyun ve biyolojik çeşitliliğin korunması gibi esaslara yer verilmiştir. Kuşkusuz WGE, BAAK bünyesindeki tek çalısma grubu değildir. Ekonomik İş Birliği (WGEC), Avro-Arktika Taşımacılık Alanı için Yönetim Kurulu (BEATA) Kurtarma İş Birliğine Dönük Ortak Komite (JCRC) ve Barents Orman Sektör Ağı (BFSN) BAAK içerisindeki diğer çalışma gruplarını oluşturmakta, aynı zamanda Konseyin bölgesel iş birliğini geliştirme alanlarını ortaya koymaktadır. Bununla birlikte küresel ısınmanın çevresel etkileri dikkate alındığında bölgesel iş birliğinin geliştirilmesi ve kalıcılı̆̆ının sağlanmasında WGE'nin ortaya koyduğu ve gelecekte ortaya koyacağ1 planlamaların ön alacağı düşüncesindeyiz. Bir sonraki dönem başkanlığı 2021 yllına kadar Norveç'e devredilecektir.

Son olarak Danimarka, Finlandiya, İzlanda, Norveç ve İsveç’in egemen devletler, Aland ve Faroe Adaları ile Grönland'ın bağlı topraklar olarak üye olduğu İskandinav Konseyi'ne kısaca göz attığımızda ise 1952'de üye ülkelerin parlamenterleri arasında bir üst parlamento biçimde tasarlandığını görmekteyiz (Gül, 2014:7). İskandinav Konseyi son yllarda Arktik Bölgesi’ne yönelik ilgisini ve iş birliği arayışlarını artırmış görünmektedir. Nitekim 2017'de gerçekleştirilen İskandinav Bakanlar Konseyi toplantısı 
sonrasında 2018-2021 yılları arasını kapsayan iş birliği programı açıklanmışır (Nordic Partnership for the Arctic, 2018). Illgili programda; Arktika Bölgesi'ne yönelik iş birliği projesinin İskandinav Bakanlar Konseyi'nin "yenilikçi, sınırsız, görülebilir ve dışa dönük bir Kuzey bölgesi meydana getirme" vizyonuyla uyumluluk gösterdiği belirtilirken, bölgede sürdürülebilir kalkınmanın sağlanmasına katkıda bulunulması hedeflenmektedir. Bu kapsamda; yerli halkların gözetilmesi, özellikle bölgedeki çocuk ve gençlerin yaşam koşullarının iyileştirilmesi, uluslararası ölçekte yerel örgütler, STK'lar ile temasa geçilerek barışçıl ve demokratik toplum inşasının güçlendirilmesi, bölgede sürdürülebilir eneriji için yenilikçi yaklaşımlar geliştirilmesi, deniz kaynaklarından sürdürülebilir biçimde istifade edilebilmesi, sera gazı etkilerinin azaltılması gibi çevresel ve toplumsal politikalar geliştirilmesi amaçlanmaktadır. Görüldüğü gibi İskandinav Konseyi'nin de Arktika'da geleceğe dönük uluslararası ve ulusaşırı ölçeklerde iş birliğinde çevresel duyarlıllı̆ı ve sürdürebilir kalkınmayı merkez aldığı açıkça görülmektedir.

Söz konusu üç hükümetler arası forum görünümündeki örgütler içerisinde üye sayısı ve faaliyet alanının kapsamı dikkate alındığında Arktika Konseyi'nin belirgin bir biçimde öne çıtı̆̆̆ anlaşlabilmektedir. Bununla birlikte Arktika Konseyi'nin işlevselliği açısından belki de en büyük sorunun Antarktika ile karşılaştırılabilecek düzeyde yasal ve idari düzenlemelerden yoksun olmasıdır (Yılmaz ve Çiftçi, 2013:9). Bunun temel nedeni olarak Arktik Bölgesi'nde kıyıdaş ulus-devletler arasındaki hukuksal ve denizle ilgili sorunların kalıcı çözümüne yönelik bir antlaşma bulunmaması buna karşılık Antarktika'da 1959'da imzalanan Antlaşma sayesinde hem bölgenin tarafsız ve askeri unsurlardan arındırılmıss statüsünün netleştirilmesi hem de bölgesel sorunların uluslararası platformda çözümünün görece kolayllğı gösterilebilir (Kennedy, 2015:29). İlk bakışta Arktika Konseyi'nin, Barents AvrupaArktika Konseyi ve İskandinav Konseyi ile paylaştı̆̆, sürdürülebilir kalkınma, yerli halklarının durumunun gözetilmesi ve çevrenin korunmasına yönelik önlemler gibi konuları merkeze alması örgütü iddiasız ve zayıf bir görünüme itmektedir. Bununla birlikte dikkat edilirse Arktika Konseyi'nin üyeleri arasında, yukanıda değinilen hukuksal tartışmaların ve askeri güç gösterisine varabilen rekabetin odağındaki, Rusya, ABD, Kanada, Norveç ve Danimarka yer almakta ancak bu ülkeler çevresel sorunlar söz konusu olduğunda pekala işbirliğini bölgesel örgüt çerçevesinde sürdürülebilir k1labilmektedirler. Bu noktada gerek yeşil kurama (green theory) gerekse bölgeselci yaklaşıma kısaca değinmekte yarar görünmektedir.

Bölgeselci yaklaşım üzerine çalışmalar yürüten akademisyen Louise Fawcett'a göre; bölgeselcilik belirli bir bölgedeki ulus-devletlerin ve devlet dışı oyuncuların aralarında iş birliğine yönelerek ve eşgüdümlü strateji takip ederek ortak politikalar oluşturmasına göndermede bulunmaktadır (Fawcett, 2004:433). Arktika bölgesi özelinde ise 1991 yllında ABD, SSCB, Kanada, 
Danimarka, Norveç, İsveç, Finlandiya ve İzlanda tarafindan imzalanan Arktika Çevre Koruma Stratejisi'nin (AEPS) bölgeselci yaklaşım açısından önemi bölgede çevrenin korunması, yerlilere söz hakkı tanınması ve sınır aşırı çevresel kirlilikle mücadelenin 1996 yllında Arktika Konseyi'nin oluşumuna yön vermiş olmasıdır (Knecht, 2013:11). Arktika Konseyi'nde yukarıda değindiğimiz örneklerdeki temel motivasyon kaynağı olan ekonomik bütünleşme yerine sürdürülebilir kalkınma, yerli hakları, çevresel sorunlar gibi yan konular ağırlıktadır ancak küresel isınma sorununun gelecekte meydana getireceği etkiler dikkate alındığında bölgesel taleplerin bu alanlarda birikmesi tesadüf değildir. İşte tam bu noktada çevresel hassasiyetlere dönük yaklaşımları açısından yeşil kurama ve neoliberal kurumsalcillğa kısaca yer vermek düşüncesindeyiz.

Yeşil kuram, özellikle 1990'lı yıllardan itibaren küreselleşme tartışmalarının ve ulus-aşırıcillğın yükselişe geçmeye başlamasıyla birlikte, küresel ölçekte çevre sorunlarına kalıcı çözümler bulmaya çalışma noktasında uluslararası ilişkiler disiplini içerisine eklemlenmeye başlamıştır. (Ar1 ve Gökpınar, 2019:166). Yeşil kuramc1 yaklaşım, neorealistlerin hegemon bir devletin zorlamasıly olmadıkça çevresel alanda iş birliğini görmezden gelmesini ve de neoliberallerin çevresel alanda iş birliğini ulusdevletlerin kişisel çıkarları doğrultusundaki amaçlarla sınırlandırmalarını eleştirmekte, salt devletlere ve onların çıkarlarına indirgenmiş normatif yapıların etkin çözüm geliştiremeyeceğini savunmaktadır (Eckersley, 2010:257). Neoliberal kurumsalcılar ise küresel çevre sorunları gibi ulusdevletlerin kendi sınırları içerisinde çözüme kavuşturamayacağı konularda uluslararası rejim oluşturmanın yararlı olacağını savunmakta ancak çevresel değişimlerin ana nedenlerine değinmediklerinden söz konusu rejimlerin çevresel sorunlara ne şekilde kalıcı çözümler getirilebileceğine dair açılama getirememektedirler (Erçandırlı, 2014:502).

Aralarındaki yaklaşım farklılığına karşın yeşil kuramcılar ile neoliberal kurumsalcıların uzlaştı̆̆ husus ulus-devletlerin kendi başlarına geçici iş birliklerine yönelerek çevresel değişimin meydana getirdiği/getireceği sorunların üstesinden gelemeyecekleridir. İşte bu noktada küresel ısınmanın etkileri daha belirgin bir biçimde hissedilmeye başlandıkça söz konusu süreçten ilk etkilenecek yerlerden biri olacak Arktika'da günümüze oranla daha hızlı ve etkili kararlar alabilen ve bu kararları ulusal hükümetlere zorlayıc1 mekanizmalarla uygulatabilen ulus-ötesi (supranational) bir yapılanmanın yaşamsal gerekliliği bir kez daha ortaya çıkmaktadır. Küresel ısınmanın etkilerine bağlı olarak dünya ikliminde görülebilir küçük ölçekli bir $1 s 1$ artışı bile sadece bölgeyi değil, bütün yerküredeki özellikle kıyı alanlarını etkileyecek, kutuplarda donmuş vaziyette bulunan toprağın (permafrost) küresel ısınmaya bağlı olarak çözülmeye başlamasıyla oluşacak sera etkisi çevresel felaketi daha da artırıcı bir etken olarak karşımıza çıkacaktır (Akpınar, 2017:86). Bu koşullarda bölgede ulus-ötesi yapılanmaya geçiş 
sürecinin işlerlik hızı ise gelecekte bölgesel ve küresel ölçeklerde meydana gelebilecek çevresel yıkımın boyut ve şiddetiyle doğru orantılı olacaktır.

\section{Sonuç Yerine}

Arktika Bölgesi yeni binyılda birlikte zengin yeraltı kaynakları ve alternatif deniz ticaret yollarının sağlayacağı ekonomik ve ticari potansiyelle gündeme gelmektedir. Söz konusu potansiyelin, Antarktika'daki duruma benzer bir biçimde, hukuksal bir düzenleme yoluyla salt kıyıdaş ülkelerin çıkarlarına değil tüm insanlığın ortak yararına açılmaması hala çatıșma-rekabet temelli beklenti ve değerlendirmelerin öne çıkmasına neden olmaktadır. $O$ halde bölgedeki iş birliği potansiyelinin geliştirilerek süreç içerisinde Arktika'nın Gorbaçov'un hayal ettiği bir "barış alanına" dönüşebilmesi için öncelikle kıyıdaş ülkelerin daha sonra ise uluslararası toplumun Arktika'yı salt küresel ısınma sonrası meydana çıkacak zengin enerji kaynaklarının ve yeni deniz ulaşım-ticaret yollarının sağlayacağı ekonomik ve ticari kazanç merkezli değil, bölgede ortak bilimsel çalışmalara hız veren ve Arktika'daki yerli halkların ve toplulukların sosyoekonomik koşullarını ve insani gelişim düzeylerini geliştirecek kararları önceleyen politikalar geliştirmesi gerekmektedir.

Mevcut koşullar ve bölgedeki başlıca ülkelerin tutumu an itibarılyla bölgede kalıcı istikrar ve iş birliği ortamının sağlanabilmesini zora sokabilecek bir görünüm arz etse de çıkarlarının öngördüğü alanlarda yeri aralarında iş birliğine yönelebilmeleri mümkün olabilmektedir. Diğer taraftan ulus-devletlerin tek başlarına ikili veya çok taraflı ilişkiler yoluyla bölgede iş birliğini geliştirecek adımlar atmaları Arktika'nın yakın gelecekte yeni çatışma alanı haline gelme riskini ortadan kaldıramamaktadır. Bu noktada küresel düzeyde BM'nin inisiyatif almasının yanı sıra bölgede faaliyet gösteren uluslararası örgütlerin de kalıcı iş birliği potansiyelini güçlendirici önlemler almaya yönelmeleri gerekmektir. Bu noktada özellikle Arktika Konseyi ile Barents Avro-Arktika Konseyi bünyesinde oluşturulan çalışma gruplarının faaliyetlerinin gelecekte bölgesel iş birliğinin sürekliliğini sağlamada anahtar rol üstleneceği düşüncesindeyiz. Nitekim bir bağlayıcı özellik taşımamalarına karşın uzman kişilerce oluşturulan çalışma gruplarının sundukları-sunacakları raporlar bölgesel iş birliğinin yönünün belirlenmesi ve özellikle çevresel sorunlara etkin çözümler üretilmesi yönünde oldukça faydalı bir işlev görmektedirler.

Arktika Konseyi üyelerinin niteliği ve işlev alanları dikkate alındığında 1990'lı yillar sonrası ivme kazanan küreselleşme ve ulus-aşırıcılık olgularıyla uyumlu bir yapıya sahiptir ve diğer bölgesel örgütlere kıyasla Arktika'da kalıc1 iş birliği potansiyelinin değerlendirilmesi noktasında etkin rol üstlenme olasılı̆̆1 daha yüksektir. Konseyin aldığ1 kararların yansımaları bölgesel ölçekli görünse de özellikle küresel ısınmanın etkileri daha yakından hissedildikçe giderek küresel bir boyut kazanacağı açıktır. Halihazırda hükümetler arası bir platform biçiminde örgütlenmiş gözükse de özellikle 
Arktika Konseyi'nin çevresel koşulların küresel 1sınma olgusuna bağlı olarak gittikçe kötüleşeceği bir süreçte serbest pazar ekonomisi yerine çevreyi merkeze alan bir spill-over etkisiyle farklı bir bütünleşme modeli sunması mümkündür. $\mathrm{Bu}$ bağlamda küresel 1sınmanın neden olacağı doğal felaketlerin $\mathrm{y} 1 \mathrm{k} 1 \mathrm{cl}$ etkilerinin önlenemese bile mümkün olabildiğince azaltılması için gerekli iradenin gösterilebilmesi ve de etkin düzenlemelere gidilebilmesi noktasında Arktika Konseyi'nin çok kritik roller üstlenme potansiyeli bulunmaktadır. Arktika Bölgesi küresel 1sınma sürecinden en çok etkilenecek alanlardan biridir ve buranın yakın gelecekte çatışma-rekabet alanı olarak değil Antarktika'da olduğu gibi kalıcı iş birliğinin örnek alanlarından birisi olarak anılması bir tercihten çok zorunluluk gibi görünmektedir. 


\section{Kaynakça}

Akpınar, B.G. (2017), "Uluslararası Hukuk Çerçevesinden Arktik Güvenliği Politikalarının Analizi: Rusya ve ABD Örneği”, Savunma Bilimleri Dergisi, 16 (2):83-118.

Aliyev, N. (2019), "Russia's Military Capabilities in the Arctic", International Center for Defence and Security (ICDS), 25.06.2019, https://icds.ee/russias-military-capabilities-in-the-arctic/, (erişim tarihi: 19.07.2019).

Arı T. ve Gökpınar F.B. (2019). "Green Theory in International Relations", T. Ar1 ve E. Toprak (Ed.), Theories of International Relations II, Anadolu University Publication, Eskişehir, 161-178.

Arktika Arama ve Kurtarma Anlaşması (2011). İngilizce metin için; "Agreement on Cooperation on Aeronautical and Maritime Research and Rescue in the Arctic", https://www.ifrc.org/docs/idrl/N813EN.pdf, (erişim tarihi: 26.07.2019).

Arktika Uluslararası Bilimsel İş Birliğini Geliştirme Anlaşması (2017). İngilizce metin için; "Aggrement on Enhancing International Arctic Scientific Cooperation", https://oaarchive.arcticcouncil.org/handle/11374/1916, (erişim taihi: 07.09.2019).

Arktika Konseyi Resmi İnternet Sitesi, https://arcticcouncil.org/index.php/en/, (erişim tarihi: 03.04.2019).

Baev, P.K. (2010). "Russia'a Arctic Policy, Geopolitics, Mercantilism and Identity-Building", The Finnish Institute of International Affairs Briefing Paper 73, December 17, 2010, 1-8.

Bentzen, N. ve Hall M. (2017). "Arctic Continental Shelf Claims, Mapping Interests in Circumpolar North", European Parliament Research Service (EPRS) Briefing, January 2017, 1-12.

Birleşmiş Milletler Deniz Hukuku Sözleşmesi (BMDHS), 6. Bölüm, https://www.un.org/Depts/los/convention_agreements/texts/un clos/part6.htm, (erişim tarihi: 09.04.2019).

Byers, M. (2017). "Crises an international cooperation: an Arctic case study”, Sage, International Relations, 31 (4):375-402.

"Canada: Allied Forces Sharpen Cold Weather Skills Above the Arctic Circle", Defence-Point.com, 02.04.2019.

Cazala, M.S. (2016). "Rusya'dan Arktik Güvenliğine Bakışlar Yeni Soğuk Savaşı Tartışmak", Orta Asya ve Kafkasya Araștrmaları (OAKA), 10 (21):163-185. 
Eckersley, R. (2010). "Green Theory", T. Dunne, M. Kurki ve S. Smith (Ed.), International Relations Theories: Discipline and Diversity, Oxford University Press, New York, 247-265.

Encyclopedia Britannica (2019). "Arctic, Northernmost Region of the Earth, Study and Exploration”, https://www.britannica.com/place/Arctic/The-Russian-Arctic, (erişim tarihi: 19.07.2019).

Erçandırlı Y. (2014). "Yeşil Teori”, R. Gözen (Ed.), Uluslararası İlişkiler Teorileri, İletişim Yayınlanı, İstanbul, 493-515.

Gorbaçov, M. (1987). "The Speech in Murmansk at the ceremonial meeting on the occasion of the presentation of the Order of Lenin and the Gold Star Medal to the city of Murmansk", 1.10.1987. Moscow: Novosti Press Agency, pp. 23-31, erişilen kaynak; https://www.barentsinfo.fi/docs/Gorbachev_speech.pdf, (erişim tarihi: 23.07.2019).

Gül, T., “Arktik’teki Rusya: Sorun ve İşbirliği Arasında Gel-Git”, Bilge Adamlar Stratejik Araştırmalar Merkezi (BİLGESAM), 24.11.2014, 1-5, http://www.bilgesam.org/incele/1856/-arktik-teki-rusya-sorun-ve-isbirligi-arasindaki-gel-git/\#.XNUzlhQzaUk, (erişim tarihi: 11.02.2019).

"Kriz Çıkaracak Çifte Hamle... Nükleer Gözdağı", Hürriyet, 15.03.2019.

IASC Resmi Sitesi, https://iasc.info/iasc/about-iasc, (erişim tarihi: 26.07.2019).

“Iceland Chairs Arctic Council”, Iceland Monitor, 07.05.2019.

Illusat Declaration (2008). Arctic Ocean Conference, 27-29 May 2008, https://cil.nus.edu.sg/wp-content/uploads/2017/07/2008-

Ilulissat-Declaration.pdf, (erişim tarihi: 11.04.2019)

Johnson, D. (2018). "Vostok 2018: Ten Years of Russian Strategic Exercises and Warfare Preparation", NATO Review, December 20, 2018, https://www.nato.int/docu/review/2018/Also-in-2018/vostok2018-ten-years-of-russian-strategic-exercises-and-warfarepreparation-militaryexercices $/ E N /$ index.htm?utm_medium $=$ email\&utm_campaign $=$ NATO+Review+Understanding+VOSTOK+2018\&utm_content =NATO+Review+Understanding+VOSTOK+2018+CID_99126 eec46c16513a496408cf1bf88da\&utm_source $=$ Email +marketing $+\mathrm{s}$ oftware\&utm_term=READ+MORE, Erişim Tarihi: 11.04.2019.

Kavas, A.Y., "Rusya'nın Arktik Politikası ve Türkiye", Bilge Adamlar Stratejik Araştırmalar Merkezi (BİLGESAM), 20.01.2014, 
http://www.bilgesam.org/incele/78/-rusya'nin-arktik-politikasive-turkiye/\#.XNQ7ZRQzaUk, (erişim tarihi: 11.02.2019).

Kazokoğlu, C.,"8 Ülkenin Gözü Neden 'Kutup Bölgesi’nde”, BBC Türkçe, 20.02.2014.

Kennedy P. (2015), "The Arctic and Antarctica: Differing Currents of Change”, New Zealand International Review, 40 (3):29-29.

Knecht, S. (2013), "Arctic Regionalism in Theory and Practice: From Cooperation to Integration", Arctic Yearbook. 2013, 1-20.

"Kutup Sınırlarında Tarihi Anlaşma”, NTV, 15.09.2010.

"Lomonosov Bridge Could Bring Russia 5 Bln Tons of Extra Fuel", Sputnik, 01.10.2007.

Matz-Lück, N. (2009). "Planting the Flag in the Arctic Waters: Russia's Claim to North Pole", Göttingen Journal of International Law, 1 (2):235-255.

Mikkola H. (2019). "The Geostrategic Arctic, Hard Security in the High North", Finnish Institute of International Affairs (FIIA) Briefing Paper 259, April 2019, https://www.fiia.fi/wpcontent/uploads/2019/04/bp259_geostrategic_arctic.pdf， (erişim tarihi: 19.07.2019), 1-8.

Murmansk Antlaşması (2010). İngilizce metin için; "Treaty between the Kingdom of Norway and the Russian Federation concerning Maritime Delimitation and Cooperation in the Barents Sea and teh Arctic Ocean", https://www.regjeringen.no/globalassets/upload/ud/vedlegg/fol kerett/avtale_engelsk.pdf, (erişim tarihi: 25.07.2019).

Nordic Partnership for the Arctic, The Nordic Council of Minsiters' Arcitc Cooperation Programme 2018-2021, http://norden.divaportal.org/smash/get/diva2:1153655/FULLTEXT01.pdf, (erişim tarihi: 03.09.2018).

Özkan, Y., "NATO, Soğuk Savaş Sonrası En Büyük Tatbikatına Hazırlanıyor", BBC Türkçe, 10.10.2018.

Singh, A., "The Creeping Militarization of the Arctic", The Diplomat, October 16, 2013, https://thediplomat.com/2013/10/thecreeping-militarization-of-the-arctic/, (erişim tarihi: 11.03.2019).

"Rusya Yakın Tarihinin En Büyük Tatbikatına Başladı: Ordunun Üçte Biri Tatbikatta”, Sputnik Türkiye, 11.09.2018. 
Staalesen, A. (2017). "This is where Norway and Russia Continue Cooperation over Arctic Oil", The Barents Observer, September 7, 2017, https://thebarentsobserver.com/en/industry-andenergy/2017/09/where-norway-and-russia-continue-cooperationover-arctic-oil, (erişim tarihi: 13.04.2019).

Swedish Chairmanship Program 2017-2019, The Barents Euro-Arctic Region, https://www.barentsinfo.fi/beac/docs/SwedishChairmanshipprog ram2017-2019.pdf, (erişim tarihi: 12.04.2019).

Swedish Chairmanship of the Barents Euro-Arctic Council Working Group on Environment, Working Programme 2018-2019, https://www.barentsinfo.fi/beac/docs/Swedish_Chairmanship_ WGE_Working_Program_2018-2019.pdf, (erişim tarihi: 04.09.2019).

The Geography of Transport Systems, "Polar Shipping Routes", 2017, https://transportgeography.org/?page_id=412, (erişim tarihi: 09.04.2019).

US Geographical Survey (2008). "Circum Arctic Resource Appraisal: Estimates of Undiscovered Oil and Gas North of the Arctic Circle”, USGS Fact Sheet, 2008-3049.

Yılmaz, N. ve Çiftçi A. (2013). "Arktika Bölgesi’nin Siyasal Önemi ve Siyasal ve Hukuksal Statüsünün Karşlıklı Değerlendirilmesi”, Muğla Sitke Kocman Üniversitesi Sosyal Bilimler Enstitüsü Dergisi, 31: 1-16. 